\title{
ANALISIS YURIDIS HAK KREDITOR SEPARATIS PEMEGANG HAK TANGGUNGAN DALAM KEPAILITAN
}

NINA YOLANDA

Dosen Fakultas Hukum Universitas Palembang Jalan Dharmapala No. IA Bukit Besar Palembang, Telp. (0711) 440650 / (0711) 442318, Email: ninayolanda51@yahoo.co.id.

\begin{abstract}
ABSTRAK
Dalam Pasal 21 Undang-Undang No. 4 Tahun 1996 tentang Hak Tanggungan, dinyatakan bahwa jika debitor pailit, kreditor separatis pemegang hak tanggungan berhak menjual sendiri secara langsung benda yang dijadikan jaminan hak tanggungan yang disebut parate eksekusi dalam teori hukum kepailitan. Namun kedudukan eksklusif kreditor separatis pemegang hak tanggungan tadi akan menjadi lemah jika terjadi kepailitan karena akan berlaku Pasal 56 ayat 1 Undang-Undang No. 37 Tahun 2004 tentang Kepailitan yang menangguhkan hak tersebut selama 90 (sembilan puluh) hari lamanya. Muncul permasalahan yaitu bagaimana hak kreditor separatis jika terjadi kepailitan. Penelitian ini bersifat deskriptif analitis, jenis penelitian yang digunakan adalah yuridis normatif, dengan pendekatan perundang-undangan dan didukung dengan pendekatan konsep. Data sekunder berupa bahan hukum dikumpulkan melalui studi kepustakaan, bahan hukum kemudian dianalisis secara kualitatif untuk menjawab permasalahan. Hak kreditor separatis jika terjadi kepailitan menjadi lemah dan kehilangan haknya untuk masa tertentu. Hak kreditor separatis dalam kepailitan tidak selalu harus didahulukan, kedudukannya dapat dikalahkan oleh utang pajak dan upah buruh/pekerja.
\end{abstract}

Kata kunci : Kreditor Separatis, Hak Tanggungan, Kepailitan. 


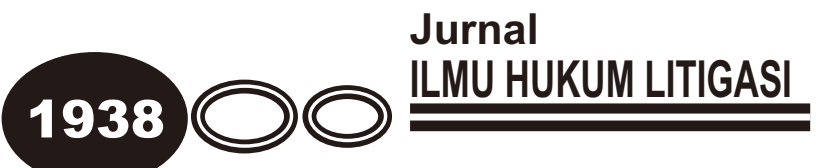

\begin{abstract}
In Article 21 Act no. 4 year 1996 on Mortgage, stated that if the debtor bankrupt, creditor "separatist" as a mortgage holder can sell their own items directly used as collateral mortgage called "parate execution" in bankruptcy law. However, the position of mortgage holders will be weak in case of bankruptcy because Article 56 paragraph 1 of Act no. 37 year 2004 will be applied, and its right will be suspended within 90 (ninety) days. Problems arise, how is creditor "separatist" rights in the event of bankruptcy. This study is a descriptive analysis, the type of research is normative, with the approach of legislation and supported the concept approach. Secondary data in the form of legal materials collected through library research, legal materials are then analyzed qualitatively to answer the problem. Secure creditor rights in the event of bankruptcy becomes weak and loses his right to a certain period. Creditor "separatist" rights in bankruptcy does not always have to come first, its position can be defeated by the tax debt and labor's wages.
\end{abstract}

Keyword: Creditors Separatists, Mortgage , Bankruptcy. 


\section{PENDAHULUAN}

Salah satu motif utama badan usaha meminjam atau memakai modal dari pihak ketiga adalah keinginan untuk meningkatkan keuntungan yang dapat diraih, baik dilihat dari segi jumlah maupun dari segi waktu, sedangkan disisi lain, salah satu motif utama pihak kreditor atau pemberi pinjaman bersedia memberi pinjaman adalah keinginan untuk memperoleh balas jasa dengan pemberian pinjaman tersebut misalnya bunga (Pande Radja Silalahi, 2001 : 203-204). Dengan demikian dapat diasumsikan bahwa untuk berkembangnya suatu perusahaan pastilah mempunyai utang.

Bagi suatu perusahaan/pengusaha, utang bukan merupakan hal yang menakutkan asalkan masih dapat dibayar kembali. Perusahaan yang dapat membayar kembali disebut perusahaan solvable (H.M.N. Purwosatjipto, 1984 : 27), artinya perusahaan yang mampu membayar utang-utangya. Sebaliknya perusahaan yang tidak dapat membayar utang-utangnya lagi (kewajibannya) disebut insolvable (H.M.N. Purwosatjipto, 1984 : 27), artinya tidak mampu membayar. Bila keadaan berhenti membayar itu benarbenar terjadi atau menjadi kenyataan, maka hakim dapat menjatuhkan pailit pada perusahaan atau orang yang bersangkutan, bahkan apabila perusahaan 


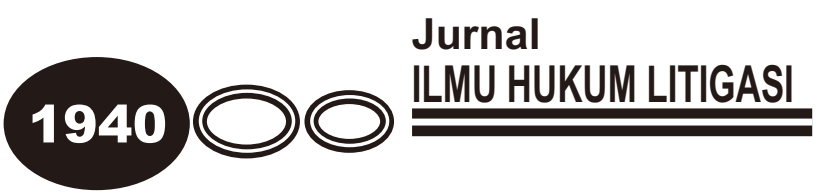

dinyatakan tidak bisa membayar utangnya lagi maka usahanya itu bisa dibilang pailit (Annalisa Y., $2007: 2$ ).

Perusahaan atau individu yang dinyatakan pailit disebut dengan debitor pailit. Debitor pailit adalah pihak yang memohon/dimohonkan pailit ke pengadilan yang berwenang. Pengadilan yang berwenang mengadili perkara kepailitan adalah Pengadilan Niaga, Pengadilan Niaga dibentuk melalui (Perpu) Nomor 1 Tahun 1998 tentang Perubahan terhadap Undangundang Kepailitan (UUK) yang ditetapkan pada tanggal 22 April 1998. Pada bulan Agustus 1998, Pengadilan Niaga dibentuk pertama kalinya pada Pengadilan Negeri Jakarta Pusat.

Debitor yang dapat dinyatakan pailit adalah debitor yang mempunyai 2 (dua) atau lebih kreditor dan tidak membayar sedikitnya 1 (satu) utang yang telah jatuh waktu dan dapat ditagih (Munir Fuady, 2005: 36). Jika seorang debitor hanya mempuyai satu kreditor dan debitor tidak membayar utangnya dengan sukarela, kreditor akan menggugat debitor secara perdata ke Pengadilan Negeri yang berwenang dan seluruh harta kekayaan debitor menjadi sumber pelunasan utangnya kepada kreditor tersebut. Hasil bersih eksekusi harta debitor dipakai untuk membayar kreditor tersebut (Imran Nating, $2004: 2-3)$. 
Menurut Pasal 1 angka 1 Undang-Undang Nomor 37 Tahun 2004 tentang Kepailitan dan Penundaan Kewajiban Pembayaran Utang (selanjutnya disebut UUK), "kepailitan adalah sitaan umum atas semua harta kekayaan debitor pailit yang pengurusan dan pemberesannya dilakukan oleh kurator di bawah pengawasan hakim pengawas sebagaimana diatur dalam undang-undang ini”. Oleh karena itu, Frederick B.G. Tumbuan menyatakan bahwa melalui sita umum akan dihindari dan diakhiri sita dan eksekusi oleh para kreditor secara sendiri-sendiri (Fred B.G. Tumbuan, 2001: 127). Dengan demikian, para kreditor harus bertindak secara bersama-sama (concursus creditorium). Dalam kepustakaan, concursus creditorium diartikan sebagai keberadaan dua atau lebih kreditor. Concursus creditorium merupakan syarat bagi kepailitan, hal ini sesuai dengan asas yang ditetapkan dalam Pasal 1132 KUH Perdata. Pasal 1132 KUHPerdata berbunyi :

"kebendaan tersebut menjadi jaminan bersama-sama bagi semua orang yang mempunyai piutang; pendapatan dari penjualan bendabenda-benda itu dibagi menurut keseimbangannya, yaiu menurut besar kecilnya piutang masing-masing, kecuali apabila seorang kreditor mempunyai alasan-alasan yang sah untuk didahului". 


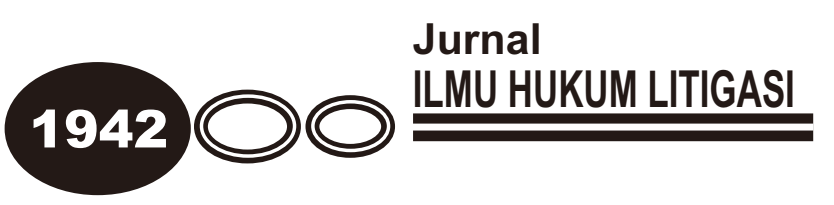

Menurut hukum kepailitan, sitaan umum mencakup seluruh kekayaan debitor untuk kepentingan semua kreditornya. Menurut penjelasan umum Pasal 2 ayat (1) Undang-Undang Nomor 37 Tahun 2004 tentang Kepailitan dan Penundaan Kewajiban Pembayaran Utang (UUK), kreditor adalah baik kreditor konkuren, kreditor separatis maupun kreditor preferen (dalam undang - undang ini tidak diatur secera tegas mengenai definisi dan macam-macam kreditor). Khusus mengenai kreditor separatis dan kreditor preferen, mereka dapat mengajukan permohonan pernyataan pailit tanpa kehilangan hak jaminan atas kebendaan yang mereka miliki terhadap harta debitor dan haknya untuk didahulukan.

Adapun penggolongan kreditor dalam kepailitan adalah (Annalisa Y., $2007: 18):$

a. Kreditor Separatis

Kreditor separatis adalah kreditor pemegang hak jaminan kebendaan (hak tanggungan, jaminan fiducia dan gadai), yang dapat bertindak sendiri. Golongan kreditor ini tidak terkena akibat putusan pernyataan pailit debitor, artinya hak-hak eksekusi mereka tetap dapat dijalankan seperti tidak ada kepailitan debitor. 
b. Kreditor Preferen Istimewa

Kreditor Preferen Istimewa adalah kreditor yang karena sifat piutangnya mempunyai kedudukan istimewa dan mendapat hak untuk memperoleh pelunasan lebih dahulu dari penjualan harta pailit. Kreditor Preferen Istimewa berada di bawah kreditor separatis;

c. Kreditor Konkuren

Dikenal juga dengan istilah kreditor bersaing, kreditor konkuren memiliki kedudukan yang sama dan berhak memperoleh hasil

penjualan harta kekayaan debitor, baik yang ada maupun yang akan ada dikemudian hari.

Pada dasarnya kedudukan para kreditor adalah sama (asas paritas creditorium) oleh karena itu, mereka mempunyai hak yang sama juga atas hasil eksekusi boedel (S. Wojowasito) pailit sesuai dengan besarnya tagihan mereka masing-masing (asas pari passu prorata parte) (Annalisa Y., 2007 : 61-62). Namun demikian, asas tersebut mengenal pengecualian yaitu golongan kreditor yang memegang hak jaminan kebendaan dan golongan kreditor yang haknya didahulukan berdasarkan undang-undang kepailitan dan 


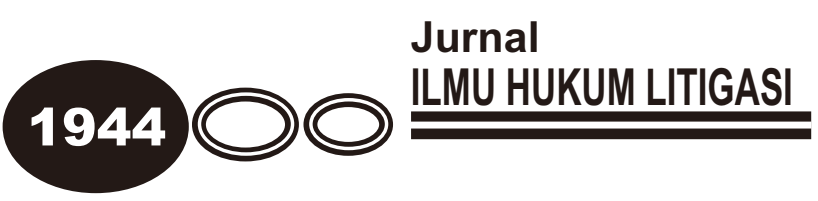

peraturan perundang-undangan lainnya. Dengan demikian asas paritas creditorium berlaku bagi para kreditor konkuren saja (Fred B.G. Tumbuan, 2001 : 128). Kreditor separatis mempunyai hak eksklusif yaitu dapat langsung mengeksekusi sendiri benda yang dijaminkan apabila debitor wanprestasi.

Berlakunya Undang-Undang Nomor 37 Tahun 2004 tentang Kepailitan dan Penundaan Kewajiban Pembayaran Utang berpengaruh besar terhadap lembaga hak tanggungan. Apabila kepailitan telah dijatuhkan kepada debitor, akan berakibat seluruh kekayaan debitor menjadi sitaan umum di bawah pelaksanaan (kekuasaan) kurator (Kurator adalah Balai Harta Peninggalan atau orang perseorangan yang diangkat oleh pengadilan untuk mengurus dan membereskan harta debitor pailit di bawah pengawasan Hakim Pengawas). Pada saat itu pula akan dikelompokkan kreditor - kreditor, mana yang masuk kreditor separatis, kreditor preferen atau kreditor konkuren.

Secara khusus pengaruh kepailitan terhadap hak tanggungan muncul dengan adanya Pasal 56 ayat (1) Undang-Undang Nomor 37 Tahun 2004 tentang Kepailitan dan Penundaan Kewajiban Pembayaran Utang. Pasal 56 ayat (1) Undang-Undang No. 37 Tahun 2004 berbunyi : 
"Hak eksekusi kreditor sebagaimana dimaksud dalam Pasal 55 ayat (1) dan pihak ketiga untuk menuntut hartanya yang berada dalam penguasaan debitor pailit atau kurator, ditangguhkan untuk jangka waktu paling lama 90 (sembilan puluh) hari sejak tanggal putusan pernyataan pailit diucapkan."

Ketentuan tersebut secara eksplisit menyatakan bahwa hak eksekusi kreditor separatis pemegang hak tanggungan terhadap hak tanggungan yang berada dalam penguasaan kreditor ditangguhkan untuk jangka waktu paling lama 90 hari (masa stay). Selama penangguhan ini obyek hak tanggungan berada dalam pengawasan kurator, peranan kurator untuk mengawasi obyek hak tanggungan ini merupakan ciri baru dalam hukum kepailitan (Sudargo, Gautama, $1998: 8)$.

Sebelum berlakunya Undang-Undang Nomor 37 Tahun 2004 tentang Kepailitan dan Penundaan Kewajiban Pembayaran Utang, dalam Undang-Undang No. 4 Tahun 1996 pengurusan dan pemberesan harta pailit dilakukan oleh Balai Harta Peninggalan (BHP). Dalam Undang - Undang Kepailitan No. 4 Tahun 1996 Pengurusan adalah seluruh harta debitor yang dinyatakan pailit dikuasai oleh curator untuk dilakukan penjualan, sedangkan 


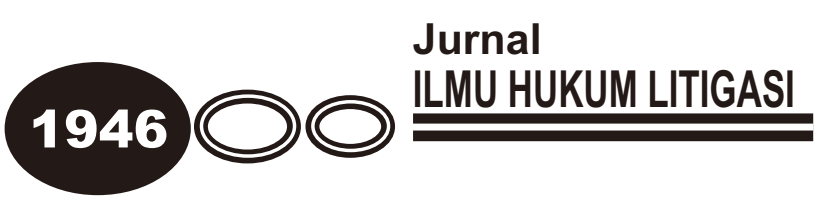

Pemberesan adalah suatu keadaan dimana kurator melakukan pembayaran kepada para kreditor konkuren dari hasil penjualan harta pailit. BHP sebagai Unit Pelaksanaan Teknis (UPT) di bawah naungan Departemen Hukum dan HAM RI diangkat selaku kurator apabila debitor atau kreditor atau pihak lain yang berwenang tidak mengajukan usul pengangkatan kurator kepada pengadilan, maka secara otomatis BHP diangkat menjadi kurator (Pasal 15 ayat (2) Undang-Undang Kepailitan).

Berlakunya norma dalam Pasal 56 ayat (1) dalam Undang-Undang Nomor 37 Tahun 2004 tentang Kepailitan dan Penundaan Kewajiban Pembayaran Utang ini bertentangan dengan norma yang ada dalam Pasal 21 Undang-Undang No. 4 Tahun 1996 tentang Hak Tanggungan. Dalam Pasal 21 Undang-Undang No. 4 Tahun 1996 tentang Hak Tanggungan dinyatakan:

“Apabila pemberi Hak Tanggungan dinyatakan pailit, pemegang Hak Tanggungan tetap berwenang melakukan segala hak yang diperolehnya menurut ketentuan Undang-Undang ini."

Norma ini memberikan hak ekslusif kepada kreditor separatis berupa parate eksekusi (eksekusi langsung benda yang menjadi jaminan debitor) jika debitor mengalami kepaillitan. 
Pertentangan kedua peraturan perundang-undangan ini layak diteliti dan diangkat menjadi sebuah tulisan ilmiah, karena pertentangan kedua peraturan perundang-undangan ini dapat menimbulkan perebutan harta pailit si debitor yang tidak menutup kemungkinan akan terjadi konflik diantara para kreditor. Perebutan harta kekayaan debitor pailit sering terjadi, misalnya pailitnya PT. Industri Pesawat Terbang Negara (PT. IPTN) yang membuat para kreditor ingin mendahulukan hak-hak mereka masing-masing, kemudian pailitnya PT. Bank IFI yang juga masing-masing kreditor ingin mendahulukan hak masing-masing.

Berdasarkan uraian di atas, yang menjadi permasalahan adalah Apa makna filosofi hak eksklusif kreditor separatis? Bagaimana Hak kreditor separatis sebagai pemegang hak tanggungan dalam kepailitan ? 


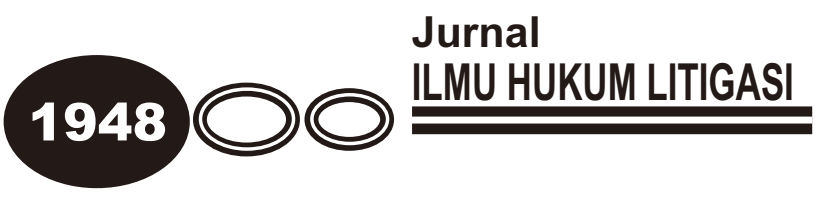

\section{METODE PENELITIAN}

Penelitian yang berjudul Analisis Yuridis Hak Kreditor Separatis Pemegang Hak Tanggungan Dalam Kepailitan ini merupakan penelitian normatif yang bersifat deskriptif-analitis. Deskriptif maksudnya bahwa dengan penelitian ini diharapkan akan diperoleh suatu gambaran yang menyeluruh dan sistematis tentang fakta yang berhubungan dengan permasalahan. Analitis dimaksudkan bahwa berdasarkan gambaran-gambaran, fakta-fakta dan uraian yang diperoleh akan dilakukan analisis secara cermat mengenai kedudukan kreditor separatis pemegang hak tanggungan dalam kepailitan (Usmawadi, $2007: 18$ ).

Pendekatan (approach) yang digunakan berkaitan dengan penelitian normatif ini adalah menggunakan pendekatan perundang-undangan (statute approach) (Bambang Waluyo, 1991 : 19), yaitu penelitian terhadap undangundang dengan mengkaji mengenai norma hak tanggungan dalam UndangUndang Nomor 37 Tahun 2004. Cara pendekatan ini dipilih selain membahas masalah yang dilakukan berdasarkan penelitian terhadap Undang-Undang Nomor 37 Tahun 2004 juga berdasarkan penelitian terhadap substansi perundang undangan yang lain, teori-teori serta doktrin yang berhubungan dengan masalah preferensi kreditor separatis pemegang hak tanggungan. 
Selain pendekatan perundang-undangan (statute approach), penulis juga menggunakan pendekatan konsep, yaitu penelitian terhadap konsep-konsep dari para sarjana dan pakar baik pakar hukum jaminan maupun pakar hukum kepailitan yang berkaitan dengan masalah preferensi kreditor separatis pemegang hak tanggungan.

Penelitian hukum normatif ini menggunakan bahan hukum berupa data sekunder yang diperoleh dari studi kepustakaan. Data kepustakaan yang ada digolongkan dalam 3 (tiga) bahan hukum, yaitu bahan hukum primer (primary sources or authorities), bahan hukum sekunder (secondary sources or authorities) dan bahan hukum tertier (Usmawadi, 2007 : 55-56). Bahan-bahan hukum primer meliputi produk-produk lembaga legislatif dan bahan hukum sekunder meliputi literatur, makalah, jurnal hukum dan artikel-artikel lain yang membahas masalah preferensi kreditor separatis pemegang hak tanggungan yang berkaitan dengan masalah yang akan diteliti. Untuk lebih jelasnya mengenai sumber data yang digunakan dalam penelitian ini terdiri dari :

a. Bahan Hukum Primer, yaitu bahan-bahan hukum yang mengikat. Dalam hal ini, bahan hukum primer yang penulis gunakan adalah :

1. Undang-Undang Nomor 37 Tahun 2004 Tentang Kepailitan dan Penundaan Kewajiban Pembayaran Utang; 


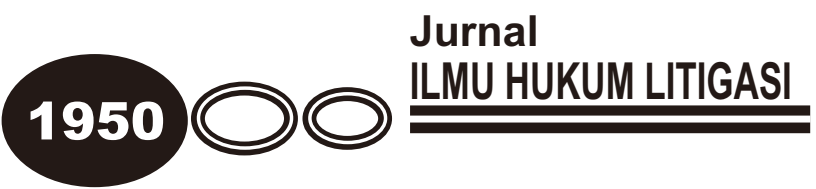

2. Undang-Undang Nomor 4 Tahun 1996 Tentang Hak Tanggungan Atas Tanah Beserta Benda-Benda Yang Berkaitan Dengan Tanah;

3. Undang-Undang Nomor 16 Tahun 2000 tentang Penagihan Pajak Dengan Surat Paksa;

4. Undang-Undang Nomor 13 Tahun 2003 tentang Ketenagakerjaan;

5. KUHPerdata (Burgerlijk Wetboek) dan peraturan perundang-undangan lain yang berkaitan dengan permasalahan yang akan diteliti;

b. Bahan Hukum Sekunder, yang memberikan penjelasan mengenai bahan hukum primer antara lain buku teks, jurnal, makalah, hasil seminar dan artikel-artikel yang berkaitan dengan kedudukan kreditor separatis pemegang hak jaminan kebendaan;

c. Bahan Hukum Tertier atau bahan hukum penunjang, diantaranya :

Bahan-bahan yang memberi petunjuk-petunjuk maupun penjelasan-penjelasan terhadap bahan hukum primer dan bahan hukum sekunder, yaitu kamus dan ensiklopedi;

Penelitian ini merupakan penelitian hukum normatif, maka bahan-bahan hukum dikumpulkan (inventarisasi) terlebih dahulu melalui studi dokumen (literature study). Selanjutnya bahan hukum tersebut digolongkan atau diklasifikasikan (clasification of law), yang mana ditentukan bahwa penelitian ini 
merupakan bagian dari hukum jaminan khususnya mengenai hak tanggungan, sehingga penelitian ini akan dapat memperoleh bahan hukum yang relevan dengan masalah yang akan diteliti (Soerjono Soekanto, $1986: 251$ ).

Berdasarkan dari hasil klasifikasi tersebut, kemudian peraturan perundang-undangan yang merupakan bahan hukum primer (primary sources or authorities) ditafsirkan atau diinterpretasikan secara sistematis, selanjutnya dikaitkan dengan karya ilmiah dari para sarjana yang merupakan bahan hukum sekunder (secondary sources or authorities) (Rianto Adi, 2004 : 92). Setelah data sekunder dikumpulkan dan diolah, maka terhadap bahan-bahan hukum yang berhasil dikumpulkan tersebut dilakukan analisis secara kualitatif. Analisis kualitatif dilakukan pada data yang tidak bisa dihitung, dalam hal ini data yang penulis analisis secara kualitatif adalah data sekunder baik bahan hukum primer, sekunder maupun tertier. Digunakannya analisis secara kualitatif karena data yang diperoleh berupa keterangan dan bahan-bahan tertulis (Usmawadi, $2007: 72$ ).

Tindakan ini dilakukan agar hasil penelitian hukum ini dapat memuat hasil dari pemikiran dan pendapat yang didasarkan pada bahan hukum yang selengkaplengkapnya dan menghasilkan laporan penelitian yang dapat diverifikasi dan diklasifikasi, pada akhirnya dari tulisan ini akan diperoleh suatu kesimpulan yang dapat menjawab permasalahan yang akan diteliti (Usmawadi, 2007 : 33). 


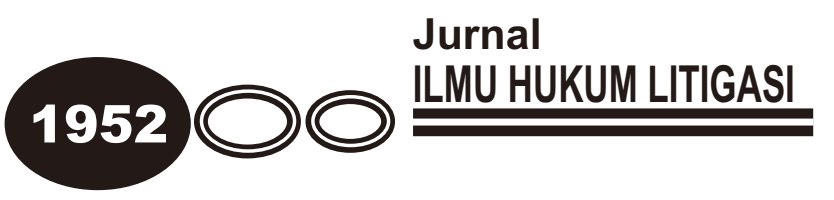

\section{HASIL PENELITIAN DAN ANALISIS}

\section{A. Makna Filosofi Kewenangan Eksklusif Kreditor Separatis}

Dana merupakan "darah" bagi suatu perusahaan dalam melakukan kegiatan bisnisnya. Seperti halnya manusia yang tidak mungkin dapat hidup tanpa darah, bagitu juga halnya dengan suatu perusahaan. Suatu perusahaan juga akan mati tanpa adanya dukungan dana. Dana bagi suatu perusahaan dapat diperoleh dari berbagai sumber. Tergantung dari sumber dana yang diperolehnya, dana suatu perusahaan dapat berupa modal (equity) dan utang (Ioan).

Dana yang berupa modal (equity) diperoleh dari para pendirinya berupa setoran modal pendiri dan diperoleh dari pemodal (investor) yang menyetorkan dana untuk modal perusahaan setelah perusahaan tersebut berdiri. Memperoleh modal bagi suatu perusahaan dapat dilakukan baik dengan menjual saham di pasar modal atau dengan cara menjual saham langsung kepada pemodal (direct placement atau private placement). Penjualan saham tentu saja hanya dapat dilakukan sepanjang perusahaan tersebut berbentuk Perseroan Terbatas (PT). Apabila perusahaan tersebut tidak berbentuk perseroan Terbatas (PT), misalnya berbentuk firma atau 
persekutuan (partnership), maka penyertaan modal oleh investor dilakukan dengan cara menjadi kongsi atau mitra perusahaan itu (Sutan Remy Sjahdeni, $1999: 11$ ).

Dana yang berupa utang (loan) dapat diperoleh perusahaan tersebut dari sumber-sumber seperti halnya bank-bank, lembaga-lembaga pembiayaan, pasar uang (financial market) yang memperjualbelikan surat-surat utang jangka pendek seperti comercial paper, pasar modal (capital market) yang memperjualbelikan surat-surat utang jangka panjang (obligasi), atau dari sumber-sumber pembiayaan lainnya. Sumber-sumber pembiayaan yang memberikan utang kepada perusahaan tersebut disebut para kreditor dari perusahaan itu. Dengan kata lain perusahaan tersebut merupakan debitor dari para kreditor tersebut (Sutan Remy Sjahdeni, 1999 : 13).

Pemberian utang oleh para kreditor (baik kreditor yang merupakan orang perorangan maupun institusional) kepada debitor sudah merupakan praktek sejak berabad-abad yang lalu dalam masyarakat. Adalah sulit pada zaman sekarang ini untuk menemukan seorang pengusaha atau suatu perusahaan yang tidak mengambil utang (pinjaman atau kredit), baik berupa utang jangka pendek maupun utang jangka panjang. Utang sudah merupakan faktor yang tidak dapat dipisahkan dari kehidupan bisnis. 


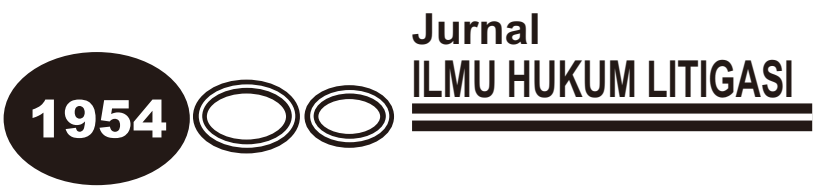

Munculnya pranata hukum berupa lembaga jaminan merupakan dasar dari pemikiran diberikannya perlindungan hukum terhadap kreditor pemegang hak jaminan kebendan yang dilandasi oleh aliran hukum alam (Theo Hujbers, 1982 : 60), yang menekankan bahwa hak seorang manusia (kreditor) untuk mendapatkan kembali haknya (piutang) dari manusia lainnya yang meminjam (debitor) untuk menunaikan kewajibannya (mengembalikan utang). Itikad baik kreditor meminjamkan uangnya kepada debitor, sebagai landasan filosofis yuridis juga tertuang secara implisit dalam Pembukaan UUD 1945 alinea IV, sebagai dasar perlindungan bagi pihak yang beritikad baik. Dalam alinea IV Pembukaan UUD 1945 dinyatakan:

"...untuk membentuk suatu pemerintahan negara Republik Indonesia yang melindungi segenak bangsa Indonesia dan untuk memajukan kesejahteraan umum, mencerdaskan kehidupan bangsa, dan ikut melaksanakan ketertiban dunia yang berdasarkan kemerdekaan, perdamaian abadi dan keadilan social".

Dalam memberikan utang, seorang kreditor tidak akan sembarangan (percaya bagitu saja) terhadap debitor yang akan mengutang. Seorang debitor butuh kepastian hukum dalam pengembalian dana yang dikeluarkannya untuk debitor tersebut. Dari sudut pandang ilmu hukum 
normatif, tujuan akhir dari hukum adalah kepastian hukum (Amir Syarifudin, 2006), hal ini senada dengan Aliran Yuridis Dogmatik, aliran ini menganggap bahwa pada dasarnya tujuan hukum adalah semata-mata untuk kepastian hukum, karena dengan kepastian hukum, fungsi hukum dapat berjalan dan mampu mepertahankan ketertiban (Purnadi Purbacaraka dan Soerjono Soekanto, $1978: 51)$.

1. Objek Jaminan Kebendaan sebagai Sumber Pelunasan Utangnya Apabila kreditor baik yang berupa lembaga keuangan seperti bank, atau lembaga pembiayaan (multi finance company), atau investor comercial paper atau obligasi (bond) memberikan kredit atau fasilitas pembiayaan kepada calon nasabahnya, maka lembaga keuangan tersebut akan memastikan bahwa kredit atau fasilitas pembiyaan itu dapat dilunasi tepat pada waktunya, baik untuk pokoknya maupun untuk bunganya. Pertamatama kreditor tersebut harus memperoleh keyakinan bahwa kegiatan usaha atau bisnis calon debitor tersebut dapat menghasilkan pendapatan yang cukup untuk melunasi kredit atau fasilitas pembiayaan tersebut. Sebelum pendapatan tersebut dipakai untuk melunasi utang perusahaan, terlebih dahulu pendapatan tersebut harus menutupi kebutuhan perusahaan dalam rangka pemupukan cadangan perusahaan dan 


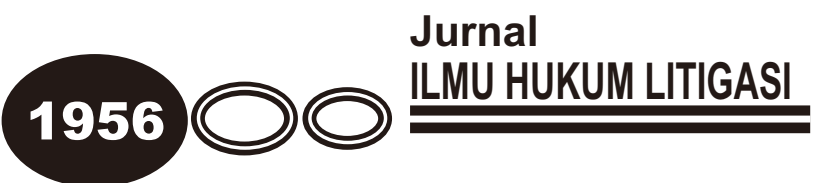

menutupi biaya-biaya operasional perusahaan. Sumber utama pelunasan utang dari pendapatan perusahaan sebagaimana yang penulis kemukakan di atas, dalam dunia perbankan disebut first way out (Sutan Remy Sjahdeni, 1999 : 23).

Apabila ternyata perusahaan mengalami kesulitan dalam usahanya sehingga perusahaan tersebut tidak memiliki kemampuan untuk menghasilkan pendapatan yang cukup untuk membayar utang-utangnya, maka para kreditor harus memperoleh kepastian bahwa hasil penjualan agunan atau hasil likuidasi atas harta kekayaan (assets) perusahaan melalui putusan pailit dari pengadilan dapat diandalkan sebagai sumber pelunasan alternatif. Disamping dari hasil penjualan agunan atau likuidasi harta kekayaan perusahaan karena perusahaan dinyatakan pailit, juga harta kekayaan penjamin (quarantor atau Borg), serta barang-barang agunan milik pihak ketiga apabila ada, dapat pula menjadi sumber pelunasan bagi utang perusahaan. Sumber pelunasan alternatif ini dalam dunia perbankan disebut second way out (Sutan Remy Sjahdeni, 1999 : 25). 
2. Kekayaan Debitor Menjadi Jaminan Utangnya

Undang-undang telah mengatur mengenai hal-hal yang berhubungan dengan second way out bagi pemberi utang oleh kreditor kepada debitor sebagimana yang penulis kemukakan di atas. Ketentuan mengenai second way out ini diatur dalam Kitab undang-Undang Hukum Perdata (KUH Perdata). Pasal 1131 KUH Perdata menentukan bahwa segala harta kekayaan debitor, baik yang berupa benda bergerak maupun benda tetap (benda tidak bergerak), baik yang sudah ada maupun yang baru akan ada dikemudian hari menjadi jaminan atau agunan bagi semua perikatan yang dibuat oleh debitor dengan para kreditornya. Dengan kata lain, Pasal 1131 KUH Perdata ini memberikan ketentuan bahwa apabila debitor cidera janji tidak melunasi utang yang diperolehnya dari para kreditornya, maka hasil penjualan atas semua harta kekayaan debitor tanpa terkecuali, merupakan sumber pelunasan bagi utangnya itu.

Ketentuan Pasal 1131 KUH Perdata tersebut merupakan ketentuan yang memberikan perlindungan bagi seorang kreditor. Seandainya ketentuan sebagaimana dimaksud dalam Pasal 1131 KUH Perdata itu tidak ada, maka sulit membayangkan akan ada kreditor yang bersedia memberikan utangnya kepada debitor. Ketentuan Pasal 1131 KUH Perdata tersebut 


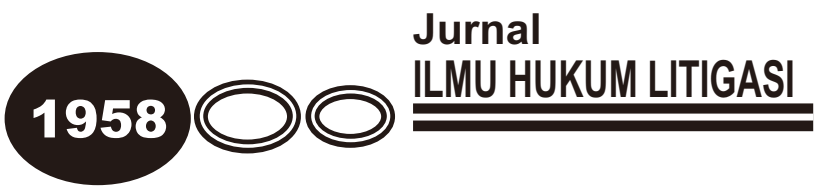

sudah merupakan asas yang bersifat universal, yang terdapat dalam setiap sistem hukum disetiap negara.

Bagaimana hasil penjualan harta kekayaan debitor itu dibagikan kepada para kreditor apabila debitor cidera janji tidak melunasi utangnya ?. Jawaban mengenai pertanyaan ini dapat dijumpai dalam pasal setelahnya yaitu Pasal 1132 KUH Perdata. Menurut Pasal 1132 KUH Perdata, harta kekayaan debitor tersebut menjadi jaminan atau agunan secara bersama-sama bagi semua pihak yang memberikan utang kepada debitor. Artinya, apabila debitor cidera janji tidak melunasi utangnya, maka hasil penjualan harta kekayaan debitor tersebut dibagikan secara proporsional (secara pari passu) menurut ketentuan besar kecilnya ragihan masingmasing kreditor, kecuali apabila ada diantara para kreditor tersebut terdapat alasan-alasan yang sah untuk didahulukan dari kreditor-kreditor lainnya.

Seperti yang sudah kita maklumi bersama, dalam hukum kepailitan kreditor separatis pemegang hak jaminan kebendaan (salah satunya pemegang hak tanggungan) mempunyai kedudukan lebih tinggi dibandingkan dengan kreditor preferen maupun kreditor konkuren dalam mengambil pelunasan utangnya, serta mempunyai keistimewaan 
dibandingkan 2 (dua) kreditor lainnya yaitu dapat mengeksekusi secara langsung objek yang dijadikan jaminan apabila debitor cidera janji (pailit).

Secara filosofis, kreditor separatis diberikan keistimewaan seperti tersebut di atas dikarenakan objek yang dijadikan jaminan sudah berada ditangan kreditor secara legal yang kemudian secara legal pula (melalui sertifikat hak tanggungan, sertifikat jaminan fiducia, surat gadai) debitor memberikan kekuasaan untuk menjual objek jaminan tersebut sebagai sumber pelunasan utangnya apabila ia ingkar janji. Jika kreditor tidak diberikan keistimewaan seperti itu, maka tidak akan ada individu maupun badan hukum yang mau meminjamkan dananya (berupa kredit maupun fasilitas pembiayaan lainnya) kepada debitor. Jadi adalah suatu hal yang wajar jika kreditor separatis sebagai pemegang hak tanggungan diberikan hak seperti tersebut di atas yang membedakan mereka dengan kreditor lainnya.

Selain itu, makna filsofis keistimewaan kreditor separatis adalah adanya kepastian hukum (jaminan) bahwa kredit atau fasilitas pembiayaan tersebut dapat dilunasi tepat pada waktunya, baik untuk utang pokok maupun bunganya, karena hanya dengan kepastian hukumlah maka individu maupun badan hukum mau memberikan fasiltas kredit kepada 


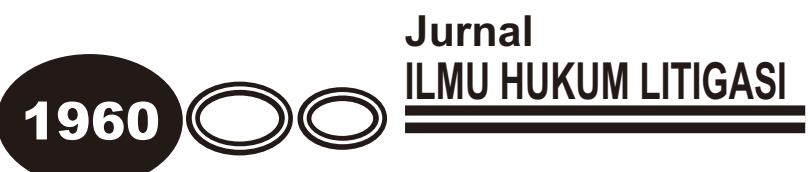

pengusaha. Pelunasan utang tersebut bersumber dari objek kebendaan yang dijadikan jaminan baik itu pelunasan secara first way out maupun pelunasan secara second way out.

Diberikannya hak untuk menjual sendiri kepada kreditor separatis sebagai pemegang hak tanggungan bertujuan agar kreditor separatis sebagai pemegang hak tanggungan memperoeh kemudahan dalam mengambil pelunasan piutangnya tanpa melalui proses yang menghabiskan biaya, waktu dan tenaga untuk menggugat debitor di pengadilan bila debitor cidera janji.

Ditinjau dari filosofis yuridis, munculnya lembaga parate eksekusi adalah agar kreditor memperoleh kemudahan dalam memperoleh pelunasan piutangnya tanpa perlu menghabiskan biaya, waktu dan tenaga untuk menggugat debitor di pengadilan bila debitor wanprestasi (cidera janji). Tanpa lembaga ini maka pihak perbankan tidak akan mau memberikan kredit kepada debitor dalam jumlah yang kecil, karena resiko biaya kredit akan tidak seimbang dengan bunga dari kredit yang diberikannya, padahal yang membutuhkan kredit bukan hanya pengusaha besar 
melainkan juga perorangan atau pengusaha kecil yang memerlukan modal dalam skala yang kecil pula.

Tidak sedikit perorangan atau perusahaan yang jatuh bangkrut karena terjerat utang kepada lintah darat yang melakukan praktek bank gelap dengan bunga tinggi, hal ini mereka lakukan karena sulitnya memperoleh kredit dari bank untuk modal usahanya. Untuk mengatasi hal ini, maka pembuat undang-undang memberikan fasiltas berupa lembaga parate eksekusi kepada kreditor untuk memperoleh pelusanan piutangnya, pertama kali melalui ketentuan dalam Pasal 1178 ayat 2 yang memberikan hak kepada pemegang hipotik pertama untuk memperjanjikan apa yang dalam bahasa belanda disebut dengan "beding van eigenmachtige verkoop" (janji untuk menjaul atas kekuasaan sendiri). Dengan memperjanjikan kewenangan seperti itu, maka dalam debitor sudah wanprestasi, kreditor bisa langsung menjual objek jaminan di muka umum tanpa harus melibatkan pihak pengadiulan terlebih dahulu (J. Satrio, 1997 : 212-213). Burgelijk Wetboek Nederland Tahun 1830 pada awalnya belum memuat kemungkinan untuk memuat "beding van eigenmachtige verkoop", baru pada Tahun 1833 ditambahkan ayat (2) pada Pasal 1223 yang isinya sama dengan Pasal 1178 ayat 2 KUH 


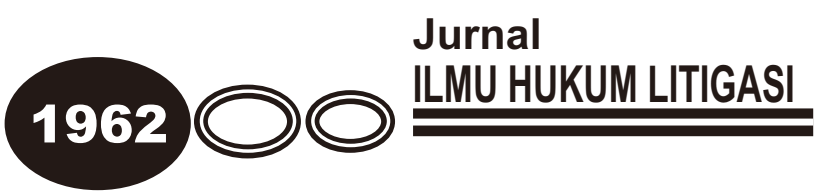

Perdata Indonesia yang seperti telah dijelaskan memberi hak kepada pemegang hipotik pertama untuk memperjanjikan hak untuk menjual atas kekuasaan sendiri (J. Satrio, $1997: 216)$.

B. Hak Kreditor Separatis sebagai Pemegang Hak Tanggungan dalam Kepailitan

Hak kreditor separatis sebagai pemegang hak tanggungan ini secara jelas telah diatur oleh Undang-Undang Nomor 4 Tahun 1996 tentang Hak Tanggungan Atas Tanah Beserta Benda-Benda Yang Berkaitan Dengan Tanah (selanjutnya disebut UUHT) Pasal 20 ayat (1) yang berbunyi :

Apabila debitor cidera janji, maka berdasarkan :

a. hak pemegang Hak Tanggungan pertama untuk menjual obyek Hak Tanggungan sebagaimana dimaksud dalam Pasal 6, atau

b. titel eksekutorial yang terdapat dalam sertifikat Hak Tanggungan sebagaimana dimaksud dalam Pasal 14 ayat (2), obyek hak tanggungan dijual melalui pelelangan umum menurut tata cara yang ditentukan dalam peraturan perundang-undangan untuk pelunasan piutang pemegang Hak Tanggungan dengan hak mendahulu dari pada kreditor lainnya. 
Di satu sisi, penangguhan eksekusi hak tanggungan oleh Pasal 56 ayat (1) Undang-Undang Kepailitan ini akan mengakibatkan permasalahan bagi kreditor pemegang hak tanggungan, yaitu terhambatnya pelaksanaan eksekusi dengan kekuasaan sendiri (parate eksekusi). Di sisi lain, secara tegas dalam Pasal 21 Undang-Undang Hak Tanggungan (UUHT), ditentukan bahwa apabila pemberi hak tanggungan (debitor) dinyatakan pailit, kreditor pemegang hak tanggungan berwenang melakukan eksekusi seolah-olah tidak terjadi kepailitan tanpa ada penangguhan. Adapun bunyi Pasal 21 Undang-Undang Hak Tanggungan (UUHT) adalah:

"Apabila pemberi hak tanggungan dinyatakan pailit, pemegang hak tanggungan tetap berwenang melakukan segala hak yang diperolehnya menurut undang-undang ini".

Ketentuan Pasal 21 Undang-Undang Hak Tanggungan (UUHT) di atas, tersirat bahwa kreditor pemegang hak tanggungan adalah sebagai kreditor separatis, dengan demikian obyek hak tanggungan tidak termasuk sebagai harta (boedel) pailit (Penjelasan Pasal 21 Undang-Undang Kepailitan). Namun dalam Penjelasan Pasal 56 ayat (1) Undang-Undang Kepailitan (UUK), dikatakan penangguhan eksekusi hak tanggungan 


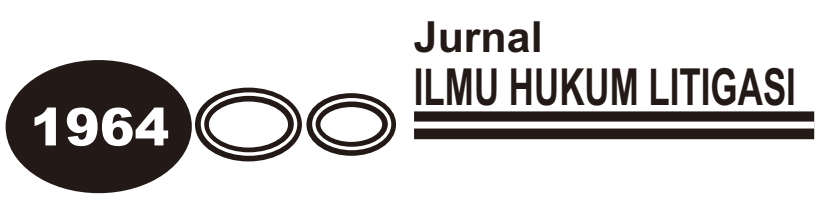

dimaksudkan untuk memperbesar kemungkinan tercapainya perdamaian, mengoptimalkan harta pailit atau kurator melaksanakan tugas secara tegas. Dari ketentuan ini, dapat disimpulkan bahwa penundaan eksekusi bukanlah semata-mata demi kepentingan kreditor belaka. Tujuan yang dimaksud oleh Pasal 56 ayat (1) Undang-Undang Kepailitan (UUK) ini sama artinya bahwa harta debitor yang sebelum kepailitan telah dibebankan dengan hak tanggungan merupakan harta pailit ketika debitor tersebut dinyatakan pailit (Sutan Remy Sjahdeini, 2002 : 284).

Hak-hak pemegang hak tanggungan yang telah dilindungi oleh Pasal 20 ayat (1) dan Pasal 21 Undang-Undang Hak Tanggungan (UUHT) tidak terlindungi lagi jika debitor dinyatakan pailit karena berlaku Pasal 56 ayat (1) Undang-Undang Kepailitan (masa stay) yang menangguhkan eksekusi pemegang hak tanggungan selama 90 hari. Ditinjau dari ilmu hukum, apa yang ditentukan dalam Undang-Undang Kepailitan (UUK) mengenai hak tanggungan khususnya yang diatur dalam Pasal 56 ayat (1) terhadap Pasal 20 ayat (1) dan Pasal 21 Undang-Undang Hak Tanggungan (UUHT) telah menyebabkan adanya benturan norma hukum (norm conflict). Hal ini disebabkan oleh adanya benturan norma hukum yang terkandung dalam 
pasal-pasal kedua undang-undang tersebut, tetapi bukan merupakan benturan aturan hukum atau undang-undang (Sutan Remy Sjahdeini, 2002 : 379).

Pelaksanaan hak-hak kreditor pemegang hak tanggungan seperti yang telah diamanatkan oleh Pasal 20 ayat (1) Undang-Undang Hak Tanggungan (UUHT) di atas, tidak semudah yang diharapkan. Hak untuk menjual dengan kekuasaan sendiri (beding van eigen machtige verkoop) masih harus memerlukan persetujuan (fiat executie) dari pengadilan. Demikian pula dalam implementasi eksekusi hak tanggungan berdasarkan kekuatan eksekutorial sertifikat hak tanggungan tidak jarang akan menghadapi perlawanan (verzet) (Sutan Remy Sjahdeini, $2002: 30$ ).

Hak dan kedudukan tertinggi dari kreditor separatis sebagai pemegang hak tanggungan seperti yang diuraikan di atas tergantung juga dengan situasi dan kondisi perusahaan atau individu yang dinyatakan pailit. Jika individu atau perusahaan tersebut mempunyai utang pajak (utang pajak merupakan salah satu kreditor preferen istimewa), maka kreditor preferen istimewa (Kreditor preferen istimewa adalah kreditor yang karena sifat piutangnya mempunyai kedudukan istimewa dan mendapat hak untuk memperoleh pelunasan lebih dahulu dari penjualan harta pailit. Dalam hukum 


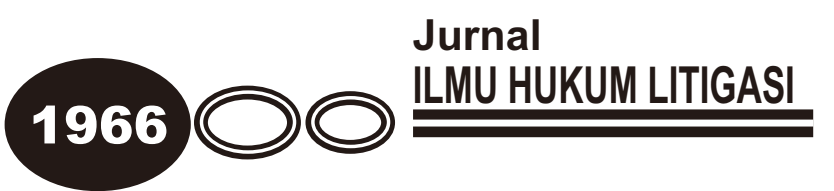

kepailitan, kreditor preferen istimewa kedudukannya di bawah kreditor separatis sebagai pemegang hak tanggungan) akan lebih tinggi dan mengalahkan kedudukan dari pada kreditor separatis sebagai pemegang hak tanggungan, dengan demikian pelunasan utangnya mendahului kreditor separatis sebagai pemegang hak tanggungan. Hal ini dapat kita jumpai dalam Pasal 19 ayat 6 Undang-Undang Nomor 16 Tahun 2000 tentang UndangUndang Penagihan Pajak dengan Surat Paksa (UUPPSP) (Penjelasan Pasal 19 ayat 6 Undang-Undang No. 19 Tahun 2000 ini menyebutkan : "menetapkan Negara sebagai kreditor preferen yang dinyatakan mempunyai hak mendahulu atas barang-barang milik Penanggung Pajak yang akan dijual kecuali terhadap biaya perkara yang semata-mata disebabkan oleh suatu penghukuman untuk melelang suatu barang bergerak dan atau suatu barang tidak bergerak, biaya yang telah dikeluarkan untuk menyelamatkan barang dimaksud, atau biaya perkara yang semata-mata disebabkan oleh pelelangan dan penyelesaian suatu warisan. Hasil penjualan barang-barang milik Penanggung Pajak terlebih dahulu untuk membayar biaya-biaya tersebut di atas dan sisanya dipergunakan untuk melunasi utang pajak"), yang isinya berbunyi : 
"hak mendahului untuk tagihan pajak melebihi segala hak mendahulu lainnya (termasuk kreditor separatis sebagai pemegang hak tanggungan, penulis), kecuali terhadap :

a. biaya perkara yang semata-mata disebabkan suatu penghukuman untuk melelang suatu barang bergerak dan atau barang tidak bergerak;

b. biaya yang telah dikeluarkan untuk menyelamatkan barang dimaksud;

c. biaya perkara yang semata-mata disebabkan pelelangan dan penyelesaian suatu warisan;

Berdasarkan ketentuan Pasal 19 ayat 6 Undang-Undang Penagihan Pajak dengan Surat Paksa (UUPPSP) tersebut, maka kedudukan kreditor preferen istimewa lebih tinggi dari pada kedudukan kreditor separatis sebagai pemegang hak tanggungan.

Selain utang pajak, kreditor preferen istimewa yang kedudukannya lebih tinggi dari pada kreditor separatis sebagai pemegang hak tanggungan adalah upah buruh yang terdapat dalam Undang-Undang Nomor 13 Tahun 2003 tentang Ketenagakerjaan, yang isinya menyebutkan bahwa tagihan yang berupa hak-hak pekerja lebih tinggi kedudukannya dari pada tagihan biasa termasuk tagihan yang dijamin dengan jaminan utang. Pasal 95 ayat 4 


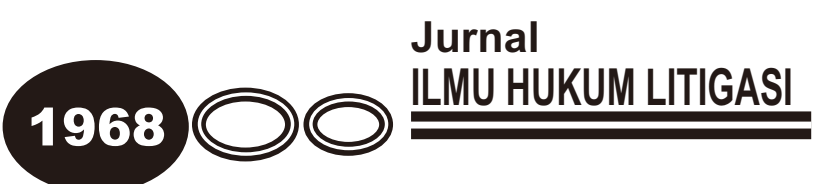

Undang-Undang Nomor 13 Tahun 2003 ini menyebutkan, pembayaran upah pekerja didahulukan apabila perusahaan pailit. Dalam penjelasan disebutkan yang dimaksud didahulukan ialah dibayar mendahului utangutang lainnya. Adapun bunyi lengkap Pasal 95 ayat 4 Undang-Undang Ketenagakerjaan adalah sebagai berikut :

"Dalam hal perusahaan dinyatakan pailit atau dilikuidasi berdasarkan
peraturan perundang-undangan yang berlaku, maka upah dan hak-hak
lainnya dari pekerja/buruh merupakan utang yang didahulukan
pembayarannya."

Adapun penjelasan ayat tersebut di atas adalah yang dimaksud dengan didahulukan pembayarannya adalah upah pekerja/buruh harus dibayar lebih dahulu dari pada utang lainnya. 


\section{SIMPULAN DAN SARAN}

\section{A. Simpulan}

1. Makna filosofi hak eksklusif kreditor separatis dalam mengambil pelunasan piutangnya merupakan timbal balik dari itikad baik (goodwill) dan kepercayaan (trust) dari kreditor yang memberikan dananya untuk debitor, oleh sebab itu undang-undang memberikan kewenangan eksklusif kepada kreditor berupa hak menguasai benda yang dijadikan objek jaminan dan dapat langsung menjual benda yang dijadikan objek jaminan tersebut jika debitor wanprestasi. Tujuan diberikannya kewenangan eksklusif ini sebagai keyakinan dan jaminan serta memberikan kepastian hukum bagi kreditor bahwa debitor akan membayar dengan kata lain memberikan kepastian bahwa dana yang telah dipinjamkannya akan kembali tepat pada waktunya dan cepat dalam pengembaliannya jika debitor wanprestasi, jika tidak demikian maka tidak akan ada individu (natuurlijke persoon) maupun badan hukum (rechtpersoon) yang mau meminjamkan dananya kepada debitor. 


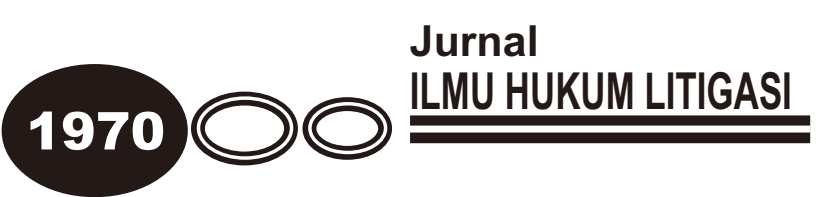

2. Hak kreditor separatis sebagai pemegang hak tanggungan dalam kepailitan secara teoritis diakui lebih tinggi dibandingkan dengan kreditor lainnya, hak kreditor separatis juga diakui dalam Pasal 32 UndangUndang No. 4 Tahun 1996 tentang Hak Tanggungan. Namun secara normatif, apabila debitor dinyatakan pailit maka kedudukan kreditor separatis sebagai pemegang hak tanggungan menjadi lemah karena berlaku Pasal 56 ayat 1 Undang-Undang Nomor 37 Tahun 2004 tentang Kepailitan dan PKPU. Disamping ketidakjelasan norma hukum yang akan dipakai, kedudukan kreditor separatis sebagai pemegang hak tanggungan juga akan melemah dan dapat dikalahkan oleh utang pajak dan utang kepada pekerja/upah buruh jika perusahaan atau individu yang dinyatakan pailit mempunyai utang pajak dan/atau utang kepada pekerja/buruh. Hal ini terlihat pada Pasal 19 ayat 4 Undang-Undang Nomor 16 Tahun 2000 tentang Penagihan Pajak Dengan Surat Paksa serta Pasal 95 ayat (4) Undang-Undang Nomor 13 Tahun 2003 tentang Ketenagakerjaan yang menyatakan bahwa utang pajak, upah pekerja/buruh harus dibayar lebih dahulu dari pada utang lainnya. 
B. Saran

Perlunya penyempurnaan Undang-Undang Kepailitan (UUK) yang mengatur eksekusi hak tanggungan agar ada 'keserasian norma hukum' yang terdapat didalam Pasal 21 Undang-Undang Hak Tanggungan (UUK) dengan Pasal 51 Undang-Undang Kepailitan (UUK), Pasal 19 ayat 4 Undang-Undang Nomor 16 Tahun 2000 tentang Penagihan Pajak Dengan Surat Paksa, Pasal 95 ayat 4 Undang-Undang Nomor 13 Tahun 2003 tentang Ketenagakerjaan. Keempat norma hukum tersebut saling berbenturan sehingga hak kreditor separatis sebagai pemegang hak tanggungan mempunyai tidak jelas harus menggunakan norma hukum yang mana. 


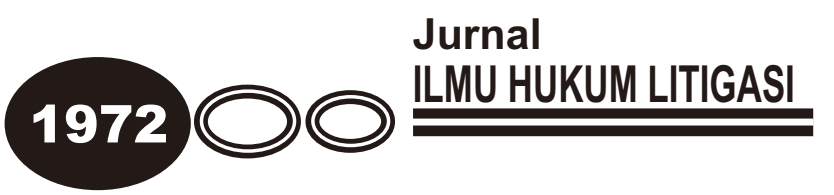

\section{DAFTAR PUSTAKA}

Annalisa Y, 2007, Kepailitan dan Penundaan Kewajiban Pembayaran Utang (Alternatif Penyelesaian Utang Piutang), Cet. I, Palembang, Penerbit Unsri.

Amir, Syarifudin, 11 Oktober 2006, Kuliah Sosiologi Hukum, Program Pascasarjana Ilmu Hukum Universitas Sriwijaya Palembang.

Frederick B.G. Tumbuan, 2001, Pokok-Pokok Undang-Undang Tentang Kepailitan Sebagaimana Diubah Oleh Perpu Nomor 1 Tahun 1978 dalam Penyelesaian Utang-Piutang Melalui Kepailitan dan Penundaan Kewajiban Pembayaran Utang, Bandung, Alumni.

H.M.N. Purwosatjipto, 1984, Pengertian Pokok Hukum Dagang Indonesia, jilid 8, Jakarta, Djambatan.

Imran Nating, 2004, Peranan dan Tangung Jawab Kurator Dalam Pegurusan dan Pemberesan Harta Pailit, Jakarta, RajaGrafindo Persada.

J. Satrio, 1997, Hukum Jaminan, Hukum Jaminan Kebendaan, Hak Tanggungan, Buku I, Bandung, Citra Aditya Bakti.

Munir Fuady, 2005, Hukum Pailit Dalam Teori dan Praktek, Edisi Revisi (disesuaikan dengan UU No. 37 Tahun 2004), Cet. III, Bandung, Citra Adtya Bakti. 
Pande Radja Silalahi, 2001, Dampak Perpu Kepailitan Terhadap Dunia Usaha, Dalam Penyelesaian Utang Piutang Melalui Pailit Atau Penundaan Kewajiban Pembayaran Utang, Editor: Rudi A. Lontoh, Bandung, Alumni.

Purnadi Purbacaraka dan Soerjono Soekanto, 1978, Perihal Kaedah Hukum, Bandung, Alumni.

Fred B.G. Tumbuan, 2001, Pokok-Pokok Undang-Undang Tentang Tentang Kepailitan Sebagaimana Diubah Oleh Perpu Nomor 1 Tahun 1978 dalam Penyelesaian Utang-Piutang Melalui Kepailitan dan Penundaan Kewajiban Pembayaran Utang, Rudi A. Lontoh, Bandung, Alumni.

S. Wojowasito, 2003, Kamus Umum Bahasa Belanda, Jakarta, PT. Ichtiar Baru Van Hoeve.

Sudargo, Gautama, 1998, Komentar atas Peraturan Kepailitan Baru Untuk Indonesia (1998), Bandung, Citra Aditya Bakti.

Sutan Remy, Sjahdeni, 1999, Hak Tanggungan Asas-Asas, Ketentuan-Ketentuan Pokok dan Masalah Yang dihadapi Oleh Perbankan, Bandung, Alumni.

Theo, Hujbers, 1982, Filsafat Hukum dalam Lintasan Sejarah, Yogyakarta, Penerbit Kanisius. 